\title{
THE INFLUENCE OF URBAN AREAS ON REGIONAL DEVELOPMENT
}

\author{
Orley M. Amos, Jr**
}

\section{Introduction}

The importance of urban areas to regional economic development has long been recognized in the literature. Policies for enhancing development in many countries have stressed the role of urban areas (Richardson, 1981). Many of the policies are based on growth pole theory first discussed by Perroux (1955) and later by Hansen (1967) and Lasuen (1969). While the growth center policy for regional development has been met with criticism (see Conroy, 1970; Darkoh, 1977; and Hansen, 1975), it can be a viable policy option if implemented carefully (Todd, 1980).

Part of the viability rests on the theoretical foundations of location theory which has recognized the influence of urban centers over the surrounding periphery since the work of von Thünen (1895). In the Thünen system the urban area is a market for products produced in the surrounding land. Therefore, proximity to the urban area is of central importance to economic activity.

The theoretical relationship between urban areas and development of the surrounding region have been well established. This paper seeks to specify and test for this relationship in the United States.

\section{The Role of Urban Areas}

In growth pole theory, an urban area acts as a seed to development for the surrounding region. Economic activity is initially concentrated at the growth pole, which then acts to disseminate development throughout the region. Forces which give use to a densely populated urban area, also make it particularly important as a central point of attaction. The most important of these forces are agglomeration economies, which tend to reduce the costs of production and allocation of goods within urban areas. In addition, agglomeration economies allow an urban area to produce and distribute many goods to the surrounding region at a lower price than local production. In that the main theme of economic development is availability of goods, the existence of an urban area can increase the level of development for the entire region. Furthermore, in that agglomeration economies increase with larger urban areas, development of the region would be greater in regions fed by larger urban areas.

\footnotetext{
"Associate Professor of Economics, Oklahoma State University.
}

The relationship between the size of an urban area and development can be demonstrated using the Thünen system, drawing on the work of Faden (1977, pp. 403415). Define: $V=$ land value, $W=$ transportation costs, and $\mathrm{D}=$ distance from urban area. Here land value is used as a proxy for the level of development in a region. Assuming cost minimization on the part of land use activity decision-makers, the following relationship can be obtained:

$$
\mathrm{V}=\mathrm{V}(\mathrm{D}) \quad \mathrm{V}^{\prime}<\mathrm{O}
$$

indicating that land value is a decreasing function of distance from the urban area. Furthermore, it can be shown that the slope of the land value function [equation (1)] is equal to transportation costs or:

$$
\left|V^{\prime}\right|=W
$$

If it is assumed that $W$ is constant, i.e., transportation costs are the same regardless of the distance from the urban area, then an autonomous increase in the value of land in the urban area would lead to an upward vertical shift of the land value function throughout the surrounding area such that, at any given distance, land values would be greater.

It can be shown that an increase in the size of the urban area would lead to an increase in V due to agglomeration economies. In the Thünen system, $V$ is the maximum amount a land use activity would be willing to pay to operate at a given location, i.e., economic profit. Land value can be defined as follows:

$$
\mathbf{V}=\mathbf{R}-\mathbf{P C}-(\mathbf{W} \cdot \mathbf{D})
$$

where $\mathbf{R}=$ gross revenue, $\mathrm{PC}=$ the opportunity costs of production, and $W$ and $D$ are as defined above. In that W D varies directly with the distance from the urban area, an activity is willing to pay more for land (V) closer to the urban area. When $\mathrm{D}=\mathrm{O}, \mathrm{V}=\mathrm{R}-\mathrm{PC}$, or what is the standard definition of economic profit in neoclassical theory, when distance is not considered.

The size of an urban area can affect both revenue and production costs in equation (1). First, a larger urban area will have a greater demand for most goods, in that more people are in the market. Therefore, revenue (R) will tend to increase with the size of an urban area. In addition, agglomeration economies will tend to reduce production 
costs (PC) in larger urban areas. Equation (3) can be rewritten as follows:

$$
\mathbf{V}=\mathbf{R}(\mathbf{S})-\mathbf{P C}(\mathbf{S})-(\mathrm{W} \cdot \mathrm{D}),
$$

where $S=$ size of the urban area.

$$
\begin{aligned}
& \text { Since } R^{\prime}>0 \text { and } P C^{\prime}<0, \\
& \frac{\partial V}{\partial S}=R^{\prime}(S)-P C^{\prime}(S)>0
\end{aligned}
$$

both for the urban area, where $D=0$, and in the surrounding region. While other factors are imporant, land value, as defined here, is a good indicator of the level of development. If a land use activity is profit-oriented, then equation (3) indicates that the land value payment $(V)$ is equal to the profit of the firm after deducting transportation costs. If a land use activity is non-profit, for example, a household, then equation (3) indicates that the land value (V) is equal to the net benefits received at the particular location. In this case the benefits are indicated by variable $R$, and the costs of obtaining the benefits are (PC $+W \cdot D)$. In this context $\mathrm{V}$, and especially changes in $\mathrm{V}$, is an indicator of the level of development, or changes in the level of development. Particularly in terms of equation (3), a higher value for $V$ implies a more efficientallocation of goods, especially if caused by a decrease in PC and/or in W. As such, the Thünen system implies that larger urban areas lead to a higher and more widespread level of development in the surrounding region.

A second factor is the accessibility of region to the urban area. From equation (1) it is evident that the level of development is less at a greater distance from the urban area. Furthermore, suppose there are two regions of different land area, but serviced by urban areas of the same size. The larger region will, on average, have a greater distance to the urban area, and, thus, a lower level of development. From equation (1), $V^{\prime}<0$ indicates that accessibility to the urban area is an important determinant of development in the surrounding region.

Another aspect of accessibility involves transportation costs (W). Not only is the average distance to the urban area important, but the ease (in terms of costs) in reaching the urban area is also significant. From equation (2):

$$
\frac{\partial \mathrm{V}}{\partial \mathrm{W}}=\mathrm{D}<\mathrm{O},
$$

indicating that reduced transportation costs lead to a higher level of development in the surrounding region. Furthermore, in reference to equation (2), since the slope of the land value function is equal to transportation costs, areduction in these costs will flatten out the function. This indicates a more widespread level of development throughout the region.

In analysis of the Thünen system, two factors are important in determining the level of regional development, the size of the central urban area and accessibility to the urban areas.

\section{Methodology and Expectations}

To test for the influence urban areas have on regional development, the following equation is estimated:

$$
v_{i}=\alpha+\beta_{1} S_{i}+\beta_{2} D_{i},
$$

where $V_{i}=$ the level of development in region $i, S_{i}=a$ measure of city-size in region $i$, and $D_{i}=a$ measure of accessibility of the population in region $i$ to the urban area.

According to the section on the role of urban areas, expected signs of the coefficients are $\beta_{1}>0$ and $\beta_{2}<0$. The larger the urban area $\left(S_{1}\right)$, acting as the central point of attraction, the greater regional development $\left(V_{i}\right)$ is expected to be $\left(\beta_{1}>0\right)$. The more distant, on average, the population of the region from the central urban areas $\left(D_{i}\right)$, then the lower regional development is expected to be $\left(\beta_{2}\right.$ $<0)$.

For a comprehensive testing of the hypothesis, the variables in equation (7) have alternative specifications for three decennial years-1960,1970, and 1980. The regions under study are United States states, ${ }^{1}$ providing for large variation in land area (and, thus, accessibility) and city-size. Three measures of city-size $\left(\mathbf{S}_{\mathbf{i}}\right)$ are employed: (1) population of the largest SMSA in the state (PCPOP), ${ }^{2}$ (2) total population of all SMSA's in the state (SMSAPOP), and (3) total population in urbanized areas in the state (UAPOP).

Each of the three measures of city-size provides a slightly different interpretation of the city-size hypothesis. The simplest interpretation of the hypothesis leads to use of the largest SMSA in the state as the central point of attraction (PCPOP). In some United States states (e.g., Colorado with Denver, and Minnesota with MinneapolisSt. Paul) a single SMSA clearly dominates other urban areas in the state. However, many states have multiple urban areas, each exerting an influence over the state (e.g., California with Los Angeles and San Francisco, and Texas with Dallas-Ft. Worth and Houston). It is for this reason that both SMSAPOP and UAPOP are used as citysize variables. But while both SMSAPOP and UAPOP contain total population figures, UAPOP uses a stricter definition of urban than SMSAPOP. While SMSAs include complete counties, urbanized areas do not. As such, UAPOP more fully reflects urbanization than does SMSAPOP. 
The use of UAPOP also partially, although not completely, avoids the problem of outlying areas within a state. That is, an area within a state might be far from the largest SMSA within the state, and, thus, have a predicted low level of development. However, if it is located near the largest SMSA in an adjoining state, then its development and, thus, the average development in the state, is greater. This is a major drawback to using states as the geographic area of observation. However, the appropriate data necessary to complete this analysis were not available for a more "idealized" type of region.

Six measures ${ }^{3}$ of accessibility are used. The first three variables are: (1) miles of interstate highway in each state (INT), (2) miles of primary highway (including interstate) in each state (PHWY), and (3) miles of municipal and rural highway in each state (MRHWY). The second three variables of accessibility are INT, PHWY and MRHWY divided by land area in the respective states (INTDN, PHWYDN and MRHWYDN, respectively). These give measures of transportation density and enable a slightly different interpretation of the accessibility hypothesis than INT, PHWY and MRHWY. Using highway miles alone will indicate the general distance of the population from the urban areas (i.e., greater highway miles are required in larger states). Therefore, $\beta_{2}<0$ for each of these three measures of $D_{i}$. However, highway density indicates the accessibility of the population to urban areas. That is, if two states have equal land area, yet one has greater highway miles, and, thus, greater highway density, its population is likely to have greater accessibility to the urban areas. In this case, it is expected that $\beta_{2}$ $>0$.

Five measures of development are used as the dependent variable $(\mathrm{V}$ ) in equation ( 7$)$. They are:

1. per capita income ( $\mathrm{PCI})$,

2. quality of life (QOL),

3. quality of living conditions (QLC),

4. quality of economic states (QES), and

5. quality of health and welfare (QHW).

Per capita income is the most common measure of regional development used throughout the literature. However, it is an imperfect measure of development. In particular, the state per capita income used here is nominal, rather than real. Thus, differential price levels in each state are not accounted for in the data. In addition, others have extensively discussed the imperfections of economic variables (Nordhaus and Tobin, 1972), such as PCI, in measuring human welfare and development, and, therefore, such variables need not be elaborated on here. Due to these limitations on the use of per capita income, the last four measures of development are also used in an attempt to include noneconomic dimensions of development.

The four measures of QOL, QLC, QES and QHW are obtained from Liu (1975). While they are also frought with imperfections (see Seidman, 1977), they are used cautiously here as supplemental data. In that per capita income is an imperfect measure of development, it is important to consider these alternative measures. In this case the best analogy is the five blind men trying to describe an elephant. Per capita income is only one aspect of development. The use of Liu's measures of quality of life, quality of living conditions, quality of economic states, and quality of health and welfare, are other aspects of development. The results of this analysis can only be strengthened by these extensions. It also should be noted that the analysis of quality of life is limited to the year 1970 , while the only analyses are for 1960, 1970, and 1980.

\section{Results}

The results of this study are presented in four subsections. First, analysis is presented based on per capita income, the three city-size variables, and total highway mileage; the second analysis includes highway density; the third analysis is based on Liu's quality of life data; and the fourth incorporates a limited time series analysis between the years 1960 and 1970, and 1970 and 1980 .

\section{Total Highway Mileage and City-Size}

Tables 1, 2, and 3 present regression estimates of equation (7) using PCPOP, SMSAPOP, and UAPOP, respectively, as the city-size variables. In all three tables $\mathrm{PCI}$ is the dependent variable and total highway mileage is used to measure accessibility.

Looking first at Table 1, it is evident that the variables for both city-size and accessibility have the expected sign, positive and negative, respectively. In all nine equations in Table 1, PCPOP is highly significant. For all three years the highway variables are all significant at the five percent level, which indicates support for both the city-size and accessibility hypotheses.

Furthermore, the coefficients for PCPOP provide additional insight into the relationship between city-size and development. For 1960, 1970, and 1980 the coefficients are consistently greater, indicating an increase in PCI, resulting from an increase in population of the primary city in the state. Thus, in 1960 an increase in population by 1,000 would increase PCI by about $\$ 120$. For 1980 the corresponding PCI increase would be over \$350. Note, however, that the PCI data are in nominal terms. When adjusted for price increases from 1960 to $1980, \mathrm{PCI}$ is increased less in 1970 than in 1960, and less 
Table 1

Regression Results Using Per Capita Income and Population of Largest SMSA: 1960,1970 and 1980

\begin{tabular}{ccccccc}
\hline \hline Year & Constant & PCPOP & INT & PHWY & MRHWY & $R^{2}$ \\
& & & & & \\
(F-value)
\end{tabular}

NOTE: Asterisks indicate the level of statistical significance- $0.10\left({ }^{*}\right), 0.05\left(^{* *}\right)$ and $0.01\left({ }^{* * *}\right)$.

in 1980 than in 1970. This indicates that, while city-state affects PCI (and, thus, development), the influence is apparently lessening over time.

The same conclusions are reached for the highway variables. While distance away from urban areas is important in determining PCI, this importance is lessening. Further evidence is provided by the decreasing $R^{2}$ 's from 1970 to 1980.

Table 2, which presents results when SMSAPOP is used as the city-size variable, has results and conclusions similar to those found in Table 1. As before, the city-size variable is positive and significant throughout. In addition, the highway variables are all negative and significant. Also the $\mathbf{R}^{2}$ 's, for 1980 are lower than for 1970 , indicating the reduced influence of urban areas and accessibility to urban areas, and adjustment of PCI for price increases shows reduced coefficients.

The main difference between Tables 1 and 2 lies in the relative size of the $R^{2}$ 's. In Table 2 , the $R^{2}$ 's, are greater than the corresponding equations in Table 1. It was stated earlier that SMSAPOP should be a better measure of urban influence over the surrounding region, in that many 
Table 2

Regression Results Using Per Capita Income and

Total SMSA Population: 1960, 1970 and 1980

\begin{tabular}{|c|c|c|c|c|c|c|}
\hline \multirow[b]{2}{*}{ Year } & \multirow[b]{2}{*}{ Constant } & \multicolumn{5}{|c|}{ Accessibility Variable } \\
\hline & & РCPOP & INT $\quad$ F & PHWY $\quad M$ & MRHWY & $\begin{array}{l}\mathrm{R}^{2} \\
\text { (F-value) }\end{array}$ \\
\hline 1960 & $\begin{array}{l}2142.84 \\
(24.4821)^{* * *}\end{array}$ & $\begin{array}{c}.0953 \\
(5.0068)^{* * *}\end{array}$ & $\begin{array}{c}-.3675 \\
(-3.2535)^{* * *}\end{array}$ & - & - & $\begin{array}{c}.3482 \\
(72.5507)^{* * *}\end{array}$ \\
\hline 1970 & $\begin{array}{l}3924.88 \\
(32.7464) * * *\end{array}$ & $\begin{array}{c}.1288 \\
(5.6331)^{* * * *}\end{array}$ & $\begin{array}{c}-.6449 \\
(-4.1463)^{* * *}\end{array}$ & - & $\longrightarrow$ & $\begin{array}{c}.4047 \\
(15.9781)^{* * *}\end{array}$ \\
\hline 1980 & $\begin{array}{l}9491.01 \\
(32.1294) * * *\end{array}$ & $\begin{array}{c}.2032 \\
(3.7446)^{* * *}\end{array}$ & $\begin{array}{l}-1.1297 \\
(-2.7737)^{* * *}\end{array}$ & - & - & $\begin{array}{c}.2298 \\
(7.0120)^{* * *}\end{array}$ \\
\hline 1960 & $\begin{array}{l}2169.52 \\
(24.5489)^{* * *}\end{array}$ & $\begin{array}{c}.0914 \\
(5.1915)^{* * *}\end{array}$ & - & $\begin{array}{c}-.0597 \\
(-3.5530)^{* * *}\end{array}$ & - & $\begin{array}{c}.3705 \\
(13.8334)^{* * *}\end{array}$ \\
\hline 1970 & $\begin{array}{l}3850.85 \\
(29.8593)^{* * *}\end{array}$ & $\begin{array}{c}.1053 \\
(4.7161)^{* * *}\end{array}$ & - & $\begin{array}{c}-.07556 \\
(-3.0648)^{* * *}\end{array}$ & - & $\begin{array}{c}.3224 \\
(11.1817)^{* * *}\end{array}$ \\
\hline 1980 & $\begin{array}{l}9436.61 \\
(30.9144)^{* * *}\end{array}$ & $\begin{array}{c}.1596 \\
(3.4183)^{* * *}\end{array}$ & - & $\begin{array}{c}-.1286 \\
(-2.4079)^{* *}\end{array}$ & - & $\begin{array}{c}.1682 \\
(5.9545)^{* * *}\end{array}$ \\
\hline 1960 & $\begin{array}{l}2143.12 \\
(23.6540)^{* * *}\end{array}$ & $\begin{array}{c}.0825 \\
(4.7920)^{* * *}\end{array}$ & - & - & $\begin{array}{l}-3.8027 \\
(-3.0875)^{* * *}\end{array}$ & $\begin{array}{c}.3361 \\
(11.8976)^{* * *}\end{array}$ \\
\hline 1970 & $\begin{array}{l}3896.90 \\
(30.5086)^{* * *}\end{array}$ & $\begin{array}{c}.1029 \\
(4.9977)^{* * *}\end{array}$ & - & - & $\begin{array}{l}-6.0153 \\
(-3.5293)^{* * *}\end{array}$ & $\begin{array}{c}.3573 \\
(13.0653)^{* * *}\end{array}$ \\
\hline 1980 & $\begin{array}{l}9397.06 \\
(27.5167)^{* * * *}\end{array}$ & $\begin{array}{c}.1303 \\
(3.0077)^{* * *}\end{array}$ & - & - & $\begin{array}{c}-.8548 \\
(-1.8706)^{*}\end{array}$ & $\begin{array}{c}.1658 \\
(4.6722)^{* *}\end{array}$ \\
\hline
\end{tabular}

NOTE: Asterisks indicate the level of statistical significance- $0.10\left(^{*}\right), 0.05^{(*)}$ and $0.01\left(^{(* *)}\right.$.

states have multiple urban centers. This speculation is born out by the higher explanatory power of equations in Table 2. Not only are $\mathbf{R}^{2}$ 's higher in Table 2, but t-values are also higher across the board.

Conclusions reached from analysis of Table 3 , which uses UAPOP for city-size, are identical to those reached thus far. The coefficients are significant and are of the expected signs. $\mathbf{R}^{2 \text { 's }}$ and "real" coefficients are less in 1980 than 1970. And, lastly, UAPOP leads to greater explanatory power than do both SMSAPOP and PCPOP, indicating, as speculated, that it is the best of the three measures of urban influence.
Tables 1,2, and 3 taken together indicate the significant but decreasing influence that urban areas, and accessibility to urban areas, have on regional development. The tables also indicate that it is the urbanized areas within each state that have the greatest influence on development.

\section{Highway Density and City-Size}

For the second analysis, the highway mileage variables (INT, PHWY and MRHWY) are replaced with corresponding highway density variables (INTDN, 
Table 3

Regression Results Using Per Capita Income and

Total Urbanized Area Population: 1960, 1970 and 1980

\begin{tabular}{|c|c|c|c|c|c|c|}
\hline \multirow[b]{2}{*}{ Year } & \multirow[b]{2}{*}{ Constant } & \multirow[b]{2}{*}{ PCPOP } & \multicolumn{3}{|c|}{ Accessibility Variable } & \multirow[b]{2}{*}{$\begin{array}{l}\mathbf{R}^{2} \\
\text { (F-value) } \\
\end{array}$} \\
\hline & & & INT & PHWY & MRHW & \\
\hline 1960 & $\begin{array}{l}2141.56 \\
(24.6454)^{* * *}\end{array}$ & $\begin{array}{c}.1086 \\
(5.1002)^{* * *}\end{array}$ & $\begin{array}{c}-.3570 \\
(-3.2314)^{* * *}\end{array}$ & - & - & $\begin{array}{c}.3567 \\
(13.0289)^{* * *}\end{array}$ \\
\hline 1970 & $\begin{array}{l}3914.48 \\
(33.1269)^{* * *}\end{array}$ & $\begin{array}{c}.1448 \\
(5.7783)^{* * *}\end{array}$ & $\begin{array}{c}-.6122 \\
(-4.1043)^{* * *}\end{array}$ & - & - & $\begin{array}{c}.4170 \\
(16.8089)^{* * *}\end{array}$ \\
\hline 1980 & $\begin{array}{l}9493.57 \\
(32.4529)^{* * *}\end{array}$ & $\begin{array}{c}.2354 \\
(3.8840)^{* * *}\end{array}$ & $\begin{array}{l}-1.0937 \\
(-2.7956)^{* * *}\end{array}$ & 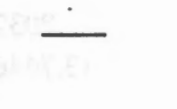 & - & $\begin{array}{l}.2430 \\
(7.5439)^{* * * *}\end{array}$ \\
\hline 1960 & $\begin{array}{l}2170.13 \\
(24.7644) * * *\end{array}$ & $\begin{array}{c}.1051 \\
(5.3113)^{* * *}\end{array}$ & - & $\begin{array}{c}-.0589 \\
(-3.5646)^{* * *}\end{array}$ & - & $\begin{array}{c}.3811 \\
(14.4688)^{* * *}\end{array}$ \\
\hline 1970 & $\begin{array}{l}3849.72 \\
(30.3551)^{* * *}\end{array}$ & $\begin{array}{c}.1222 \\
(4.9490)^{* * *}\end{array}$ & - & $\begin{array}{c}-.0744 \\
(-3.1175)^{* * *}\end{array}$ & - & $\begin{array}{c}.3438 \\
(12.3095)^{* * *}\end{array}$ \\
\hline 1980 & $\begin{array}{l}9435.61 \\
(31.1605)^{* * *}\end{array}$ & $\begin{array}{c}.1871 \\
(3.5480)^{* * *}\end{array}$ & - & $\begin{array}{c}-.1250 \\
(-2.4104)^{* *}\end{array}$ & - & $\begin{array}{c}.2143 \\
(6.4080)^{* * *}\end{array}$ \\
\hline 1960 & $\begin{array}{l}2144.21 \\
(23.8719)^{* * *}\end{array}$ & $\begin{array}{c}.0953 \\
(4.9189)^{* * *}\end{array}$ & - & - & $\begin{array}{l}-3.7659 \\
(-3.1054)^{* * *}\end{array}$ & $\begin{array}{c}.3476 \\
(12.5211)^{* * *}\end{array}$ \\
\hline 1970 & $\begin{array}{l}3892.53 \\
(30.9263)^{* * *}\end{array}$ & $\begin{array}{c}.1188 \\
(5.2000)^{* * *}\end{array}$ & - & - & $\begin{array}{l}-5.8677 \\
(-3.5463)^{* * *}\end{array}$ & $\begin{array}{c}.3752 \\
(14.1135)^{* * *}\end{array}$ \\
\hline 1980 & $\begin{array}{l}9401.03 \\
(27.7636)^{* * *}\end{array}$ & $\begin{array}{c}.1565 \\
(3.1649)^{* * * *}\end{array}$ & - & - & $\begin{array}{c}-.8522 \\
(-1.8990)^{*}\end{array}$ & $\begin{array}{c}.1800 \\
(5.1600)^{* * * *}\end{array}$ \\
\hline
\end{tabular}

NOTE: Asterisks indicate the level of statistical significance- $0.10(*), 0.05\left(^{* *}\right)$ and $0.01\left(^{* * *}\right)$.

PHWYDN, and MRHWYDN). Presented in Table 4 are regression estimates of Equation (7) using UAPOP and the three highway density variables. As might be expected, regression results using PCPOP and SMSAPOP are related to the results in Table 4 in the same manner that Tables 1 and 2 are related to Table 3. Therefore, results using PCPOP and SMSAPOP in combination with highway density variables are not presented here.

While all highway density coefficients are positive as expected, only in 1970 are they statistically significant. This indicates that highway density is not as good a measure of accessibility as highway mileage is of inaccessibility. Part of this may lie in the density measure itself, because greater highway density may not, in itself, enable greater accessibility to urban areas. It is possible that highway density becomes so high in some states that accessibility might actually be reduced due to the land area taken up by the highways and the complexity involved in accessing the highways. This might explain the general lack of statistical significance by the highway density variables in Table 4. 


\section{Table 4}

Regression Results Using Per Capita Income, Using Total Urbanized Area Population and Highway Density Variables: 1960, 1970 and 1980

\begin{tabular}{|c|c|c|c|c|c|c|}
\hline \multirow[b]{2}{*}{ Year } & \multirow[b]{2}{*}{ Constant } & \multicolumn{5}{|c|}{ Accessibility Variable } \\
\hline & & PCPOP & INT & PHWY 1 & MRHWY & $\begin{array}{l}\mathbf{R}^{2} \\
\text { (P-value) }\end{array}$ \\
\hline 1960 & $\begin{array}{l}1849.90 \\
(21.5394)^{* * *}\end{array}$ & $\begin{array}{c}.0627 \\
(3.1408)^{* *}\end{array}$ & $\begin{array}{c}4.9423 \\
(1.3528)\end{array}$ & - & - & $\begin{array}{c}.2432 \\
(7.5523)^{* * *}\end{array}$ \\
\hline 1970 & $\begin{array}{l}3414.77 \\
(29.6972)^{* * *}\end{array}$ & $\begin{array}{c}.0697 \\
(3.1649)^{* * *}\end{array}$ & $\begin{array}{c}7.5559 \\
(1.8213)^{*}\end{array}$ & - & - & $\begin{array}{c}.2603 \\
(8.2679)^{* * * *}\end{array}$ \\
\hline 1980 & $\begin{array}{l}8758.74 \\
(33.1819)^{* * * *}\end{array}$ & $\begin{array}{c}.1092 \\
(2.3671)^{* *}\end{array}$ & $\begin{array}{l}6.8968 \\
(.8293)\end{array}$ & - & - & $\begin{array}{c}.1299 \\
(3.5072)^{* *}\end{array}$ \\
\hline 1960 & $\begin{array}{l}1855.98 \\
(20.5269)^{* * * *}\end{array}$ & $\begin{array}{c}.0622 \\
(3.2580)^{* * * *}\end{array}$ & - & $\begin{array}{c}.6700 \\
(1.1345)\end{array}$ & - & $\begin{array}{c}.2347 \\
(7.2070) * * *\end{array}$ \\
\hline 1970 & $\begin{array}{l}3366.63 \\
(27.0700)^{* * * *}\end{array}$ & $\begin{array}{c}.0678 \\
(3.0954) * * *\end{array}$ & - & $\begin{array}{l}1.6210 \\
(2.0631)^{* *}\end{array}$ & - & $\begin{array}{c}.2738 \\
(8.8609)^{* * * *}\end{array}$ \\
\hline 1980 & $\begin{array}{l}8787.46 \\
(27.3399)^{* * * *}\end{array}$ & $\begin{array}{c}.1115 \\
(2.3956)^{* * *}\end{array}$ & - & $\begin{array}{c}.8268 \\
(.4242)\end{array}$ & - & $\begin{array}{c}.1205 \\
(3.2196)^{* *}\end{array}$ \\
\hline 1960 & $\begin{array}{l}1853.02 \\
(18.0038)^{* * *}\end{array}$ & $\begin{array}{c}.0619 \\
(3.1699)^{* * *}\end{array}$ & - & - & $\begin{array}{r}57.4019 \\
(.9454)\end{array}$ & $\begin{array}{c}.2284 \\
(6.9569)^{* *}\end{array}$ \\
\hline 1970 & $\begin{array}{l}3364.00 \\
\quad(23.5559)^{* * *}\end{array}$ & $\begin{array}{c}.0690 \\
(3.0892)^{* * * *}\end{array}$ & - & - & $\begin{array}{r}128.1420 \\
(1.6571)\end{array}$ & $\begin{array}{c}.2518 \\
(7.9073)^{* * *}\end{array}$ \\
\hline 1980 & $\begin{array}{l}8707.27 \\
(27.3206)^{* * *}\end{array}$ & $\begin{array}{c}.1096 \\
(2.3724)^{* *}\end{array}$ & - & - & $\begin{array}{r}11.6088 \\
(.7659)\end{array}$ & $\begin{array}{c}.1280 \\
(3.4499)^{* * *}\end{array}$ \\
\hline
\end{tabular}

NOTE: Asterisks indicate the level of statistical significance- $0.10\left(^{*}\right), 0.05\left(^{(* *}\right)$ and $0.01\left({ }^{* * *}\right)$.

Quality of Life as a Measure of Development

Table 5 presents regression results of estimating equation (7) using four separate quality of life variables as dependent variables instead of PCI. Based upon the conclusions of the first two sections, only the results obtained from using UAPOP, INT, PHWY, and MRHWY as dependent variables are presented. Results using the excluded variables correspond to Table 5 analogously to the correspondence for earlier results.
As with Tables 1 through 4, all signs in Table 5 are as expected. The coefficients on UAPOP are positive and those on the highway variables are negative. However, the $R^{2}$ 's in Table 5 are generally lower than earlier equations, and over half of the highway coefficients are not statistically significant. Thus, while results in Table 5 are supportive of the city-size hypothesis, they are less supportive of the accessibility hypothesis. But taken together with the results of Tables 1 through 4, Table 5 adds additional support for the two hypotheses. 


\section{Table 5}

Regression Results Using Quality of Life Variables and Total Urbanized Area Population: 1970

\begin{tabular}{|c|c|c|c|c|c|c|}
\hline \multirow{2}{*}{$\begin{array}{l}\text { Depeadent } \\
\text { Variable }\end{array}$} & \multirow[b]{2}{*}{ Constant } & \multicolumn{5}{|c|}{ Accessibility Variable } \\
\hline & & UAPOP & INT & PHWY 1 & MRHWY & $\begin{array}{l}\mathbf{R}^{2} \\
\text { (F-value) }\end{array}$ \\
\hline QOL & $\begin{array}{l}102.17 \\
(23.6744)^{* * *}\end{array}$ & $\begin{array}{c}.0022 \\
(2.3885)^{* *}\end{array}$ & $\begin{array}{c}-.0091 \\
(-1.6223)\end{array}$ & - & - & $\begin{array}{c}.1084 \\
(2.8574)^{*}\end{array}$ \\
\hline QLC & $\begin{array}{l}107.53 \\
(22.4201)^{* * *}\end{array}$ & $\begin{array}{c}.0030 \\
(2.2969)^{* *}\end{array}$ & $\begin{array}{c}-.0175 \\
(-2.8904)^{* * *}\end{array}$ & - & - & $\begin{array}{c}.1827 \\
(5.2537)^{* * * *}\end{array}$ \\
\hline QES & $\begin{array}{l}96.58 \\
(13.8915)^{* * *}\end{array}$ & $\begin{array}{c}.0047 \\
(3.2124)^{* * *}\end{array}$ & $\begin{array}{c}-.0096 \\
(-1.0979)\end{array}$ & - & - & $\begin{array}{c}.2031 \\
(5.9876)^{* * *}\end{array}$ \\
\hline QHW & $\begin{array}{l}104.32 \\
(28.6664)^{* * *}\end{array}$ & $\begin{array}{c}.0020 \\
(2.6481)^{* *}\end{array}$ & $\begin{array}{c}-.0014 \\
(-2.4919)^{* *}\end{array}$ & - & - & $\begin{array}{c}.1463 \\
(4.0271)^{* *}\end{array}$ \\
\hline QOL & $\begin{array}{l}104.11 \\
(23.7664)^{* * * *}\end{array}$ & $\begin{array}{c}.0023 \\
(2.7362)^{* * *}\end{array}$ & - & $\begin{array}{c}-.0018 \\
(-2.2108)^{* * *}\end{array}$ & - & $\begin{array}{c}.1472 \\
(4.0552)^{* *}\end{array}$ \\
\hline QLC & $\begin{array}{l}105.56 \\
(21.0775)^{* * *}\end{array}$ & $\begin{array}{c}.0024 \\
(2.4374)^{* *}\end{array}$ & - & $\begin{array}{c}-.0021 \\
(-2.2249)^{* *}\end{array}$ & - & $\begin{array}{c}.1292 \\
(3.4854)^{* *}\end{array}$ \\
\hline QES & $\begin{array}{l}96.90 \\
(13.7900) * * *\end{array}$ & $\begin{array}{c}.0046 \\
(3.3455)^{* * *}\end{array}$ & - & $\begin{array}{r}-.0015 \\
(-1.0183)\end{array}$ & - & $\begin{array}{c}.2045 \\
(6.0405)^{* * *}\end{array}$ \\
\hline QHW & $\begin{array}{l}100.50 \\
(25.9385)^{* * *}\end{array}$ & $\begin{array}{c}.0012 \\
(1.6409)\end{array}$ & - & $\begin{array}{c}-.0007 \\
(-1.0183)\end{array}$ & - & $\begin{array}{c}.0544 \\
(1.3512)\end{array}$ \\
\hline QOL & $\begin{array}{l}101.48 \\
(22.0814) * * *\end{array}$ & $\begin{array}{c}.0018 \\
(2.1747)^{* *}\end{array}$ & - & - & $\begin{array}{c}-.0806 \\
(-1.3340)\end{array}$ & $\begin{array}{c}.0928 \\
(2.4047)\end{array}$ \\
\hline QLC & $\begin{array}{l}102.74 \\
(19.5774)^{* * *}\end{array}$ & $\begin{array}{c}.0018 \\
(1.8937)^{*}\end{array}$ & - & - & $\begin{array}{c}-.0964 \\
(-1.3967)\end{array}$ & $\begin{array}{r}.0758 \\
(-1.9274)\end{array}$ \\
\hline QES & $\begin{array}{l}93.84 \\
(12.9924)^{* * *}\end{array}$ & $\begin{array}{c}.0040 \\
(3.0840)^{* * *}\end{array}$ & - & - & $\begin{array}{c}-.0512 \\
(-.5398)\end{array}$ & $\begin{array}{c}.1877 \\
(5.4285)^{* * *}\end{array}$ \\
\hline QHW & $\begin{array}{l}99.32 \\
(25.0230)^{* * * *}\end{array}$ & $\begin{array}{c}.0010 \\
(1.4072)\end{array}$ & - & - & $\begin{array}{c}-.0311 \\
(-.5954)\end{array}$ & $\begin{array}{c}.0407 \\
(.9981)\end{array}$ \\
\hline
\end{tabular}

NOTE: Asterisks indicate the level of statistical significance- $0.10(*), 0.05\left({ }^{* *}\right)$ and $0.01\left({ }^{* * *}\right)$. 
Table 6

Regression Analysis for the Change in

Per Capita Income: 1960 to 1970 and 1970 to 1980

\begin{tabular}{|c|c|c|c|c|c|c|}
\hline \multirow[b]{2}{*}{ Period } & \multirow[b]{2}{*}{ Constant } & \multicolumn{5}{|c|}{ Accessibility Variable } \\
\hline & & UAPOP & INT & PHWY & MRHWY & $\begin{array}{l}R^{2} \\
\text { (F-value) }\end{array}$ \\
\hline $1960-1970$ & $\begin{array}{l}1632.50 \\
(41.6325)^{* * *}\end{array}$ & $\begin{array}{c}.0748 \\
(1.3829)\end{array}$ & $\begin{array}{l}.2464 \\
(.3604)\end{array}$ & - & - & $\begin{array}{c}.0743 \\
(1.8853)\end{array}$ \\
\hline $1970-1980$ & $\begin{array}{l}5430.43 \\
(42.5878)^{* * * *}\end{array}$ & $\begin{array}{l}.1284 \\
(.7785)\end{array}$ & $\begin{array}{l}-1.5026 \\
(-.5574)\end{array}$ & - & - & $\begin{array}{l}.0138 \\
(.3295)\end{array}$ \\
\hline $1960-1970$ & $\begin{array}{l}1634.43 \\
(44.4879)^{* * *}\end{array}$ & $\begin{array}{c}.0795 \\
(1.7698)^{\star}\end{array}$ & - & $\begin{array}{c}.0461 \\
(.9995)\end{array}$ & - & $\begin{array}{c}.0910 \\
(2.3534)\end{array}$ \\
\hline $1970-1980$ & $\begin{array}{l}5459.67 \\
(45.5298) * * *\end{array}$ & $\begin{array}{c}.2156 \\
(1.2743)\end{array}$ & - & $\begin{array}{c}-.1388 \\
(-1.4580)\end{array}$ & - & $\begin{array}{c}.0503 \\
(1.2437)\end{array}$ \\
\hline $1960-1970$ & $\begin{array}{l}1639.36 \\
(42.7803)^{* * *}\end{array}$ & $\begin{array}{c}.0897 \\
(1.8414)^{*}\end{array}$ & - & - & $\begin{array}{l}-1.0937 \\
(-.2155)\end{array}$ & $\begin{array}{c}.0763 \\
(1.8404)\end{array}$ \\
\hline $1970-1980$ & $\begin{array}{l}5524.47 \\
(24.5489)^{* * *}\end{array}$ & $\begin{array}{l}.1005 \\
(.6698)\end{array}$ & - & - & $\begin{array}{l}-.1403 \\
(-.4678)\end{array}$ & $\begin{array}{l}.0019 \\
(.2831)\end{array}$ \\
\hline
\end{tabular}

NOTE: Asterisks indicate the level of statistical significance- $-0.10\left(^{*}\right), 0.05\left({ }^{* *}\right)$ and $0.01\left({ }^{* * *}\right)$.

\section{Limited Time Series Analysis}

To test for the influence that urban areas have on state per capita income over time, the change in PCI was regressed on the change in city-size and on the change in highway mileage. The results for the UAPOP city-size variable are presented in Table 6. As before, results using SMSAPOP and PCPOP are similar to those for UAPOP and are not presented here. While the general level of significance of the independent variables in Table 6 is very low, some inference can be drawn from it. First of all, only the change in UAPOP from 1960 to 1970 is significant in Table 6. The corresponding variable for 1970 to 1980 is not significant. This supports the earlier contention that while urban areas influence regional development, this influence is lessening. This conclusion is supported by Table 6 in that the UAPOP t-values are less from 1970 to 1980 than from 1960 to 1970.

\section{Summary and Discussion}

This study has supported the theoretical expectations that urban areas influence the level of regional development. This influence comes from both the size of the urban area, and from accessibility to the urban area. The results indicate that states with larger primary cities, as well as urbanized areas, will have greater per capita income. In addition, more highway miles, indicating a greater distance from urban areas, will lead to reduced per capita income. Corresponding results are obtained if Liu's measures of quality of life are used as a proxy for development instead of per capita income.

These results alone are not surprising. However, the degree of influence, at least from 1970 to 1980, is apparently diminishing. The reasons for this may not be apparent immediately. But, taken in the context of the role of urban areas in regional development, one explanation is possible. 
The very fact that an urban area influences the peripheral region may have the inherent causes of the reduced influence. In that an urban area acts as a point of dominance and development leader in the region, it enables development to be dispersed throughout the region. However, as development is dispersed and the level of development is raised closer towards that of the urban area, the role of the urban area as a leader is diminished. As the peripheral area develops, it needs to look towards the urban area less and less as the central point of attraction. This appears to be the case for urban areas in the United States in recent years.

\section{NOTES}

'Data used in the study were obtained from the United States Census of Population (city-size), Statistical Abstract of the United States (highway mileage) and Survey of Current Business (per capita income).

'Alaska, Vermont and Wyoming did not contain SMSA's in 1960 and 1970. However, to provide for a consistent series, the population of the counties in 1960 and 1970, defined as SMSA's in 1980, were used as PCPOP in the earlier years.

'No 1980 highway mileage data were available, so 1979 data were used.

\section{REFERENCES}

Conroy, M. E. "Rejection of Growth Center Strategy in Latin American Regional Development Planning." Land Economics. 49 (1973). 371-380.
Darkoh, M. B. K. "Growth Poles and Growth Centers with Special Reference to Developing Countries-A Critique." Journal of Tropical Geography. 44 (1977). 12-22.

Faden, A.M. Economics of Space and Time. Ames, Iowa: Iowa State University Press, 1977.

Hansen, N. M. "Development Pole Theory in a Regional Context." Kyklos. 20 (1967). 709-725.

Lasuén, J. R. "On Growth Poles." Urban Studies. 6 (1969). 137-161.

Liu, B. C. "Quality of Life: Concept, Measure and Results." American Journal of Economics and Sociology. 34 (1975). 2-13.

Nordhaus, W. and J. Torbin. "Is Growth Obsolete?" Economic Growth. New York: National Bureau of Economic Research, 1972.

Perroux, F. "Note on the Concept of Growth Poles." In D. McKee, R. Dean, and W. Leahy (eds.). Regional Economics: Theory and Practice. New York: The Free Press, 1970. 93-104.

Richardson, H. W. "National Urban Development Strategies in Developing Countries." Urban Studies. 18 (1981). 267. 283.

Seidman, D. "Quality of Life Indicators in United States Metropolitan Areas, 1970: Review." Social Indicators Research. 4 (1977). 99-105.

Todd, D. "Welfare or Efficiency: Can the Growth Center Offer a Compromise?" Growth and Change. 11 (1980). 39-43.

von Thunen, J. H. Der Isolierte Staat in Beziehung auf Landwirtscaft und Nationalokomie. Berlin: Hempel and Parey, 1895. 